$12-3-2011$

\title{
Expanding Your Accounting Classroom with Digital Video Technology
}

Mark Holtzblatt

Cleveland State University, m.holtzblatt@csuohio.edu

Norbert Tschakert

Follow this and additional works at: https://engagedscholarship.csuohio.edu/bus_facpub

Part of the Accounting Commons

How does access to this work benefit you? Let us know!

\section{Publisher's Statement}

NOTICE: this is the author's version of a work that was accepted for publication in Journal of Accounting Education. Changes resulting from the publishing process, such as peer review, editing, corrections, structural formatting, and other quality control mechanisms may not be reflected in this document. Changes may have been made to this work since it was submitted for publication. A definitive version was subsequently published in Journal of Accounting Education, 29, (12-03-2011); 10.1016/j.jaccedu.2011.10.003

\section{Original Published Citation}

Holtzblatt, Mark, and Tschakert, Norbert. (2011). Expanding Your Accounting Classroom with Digital Video Technology. Journal of Accounting Education, 29, pp.100-121

This Article is brought to you for free and open access by the Monte Ahuja College of Business at EngagedScholarship@CSU. It has been accepted for inclusion in Business Faculty Publications by an authorized administrator of EngagedScholarship@CSU. For more information, please contact library.es@csuohio.edu. 


\title{
Expanding your accounting classroom with digital video technology
}

\author{
Mark Holtzblatt ${ }^{\mathrm{a}, *}$, Norbert Tschakert ${ }^{\mathrm{b}, 1}$
}

${ }^{4}$ Heller College of Business, Roosevelt University, 430 S. Michigan Avenue, Chicago, IL. 60605, United States

${ }^{b}$ Bertolon School of Business, Salem State University, 352 Lafayette Street, Salem, MA 01970. United States 


\section{Introduction}

Video is springing up all around us and is becoming pervasive in our everyday lives. For example, video monitors are now found in public transportation, on the top of gas station pumps, and at the checkout lines in the grocery store. Nancy Bagranoff, a past President of the American Accounting Association (AAA), invited and welcomed AAA members to the 2010 Annual Meeting held in San Francisco via the medium of video on the AAA website. Videos of all keynote speeches from both the 2010 and 2011 AAA annual meetings are archived on the AAA Commons (http://commons.aaahq.org). In September of 2011, Julie Smith David, Chief Innovation Officer (CIO) of the AAA, announced the upgrading of the AAA's video platform to deliver high-quality video and has solicited ideas from the AAA membership for video initiatives ranging from extending the reach of meetings to the support of research and teaching activities (David, 2011a).

A 2009 New York University study (Kaufmann \& Mohan, 2009) concluded that the educational use of video on campus is accelerating rapidly in departments across all disciplines from art, humanities, and sciences to professional and vocational curricula. The same study found that the demand for educationally targeted video archives and services is high. A 2011 study conducted by Pearson Learning Solutions and Babson College Survey Research Group concluded that online video is by far the most common type of social media used in class, posted outside class or assigned to students to view, with $80 \%$ of faculty reporting some form of class use of online video (Moran, Seaman, \& Tinti-Kane, 2011).

In light of these recent events and studies, it is likely that video usage will be increasing noticeably throughout the accounting curriculum. Video has been used in education for decades. However, whereas previous generations used large VCRs and bulky cathode ray tube TVs suspended from the ceiling in classrooms or located on carts, we now show videos through computers connected to projectors, interactive whiteboards or LCD monitors. We are in an era of on-demand online video learning, easy and interactive web publishing, and the wide availability of low-cost digital video camcorders. We can watch educational videos anytime and anywhere we have internet access or can create videos and contribute to internet video repositories. These digital videos are accessible from a growing number of devices including desktops, laptops, tablets and mobile phones.

In this article, we share our personal exploration of the use of online digital video technology in the accounting classroom during the past three years and our plans for the future. This encompasses the showing of video clips in "smart" classrooms, assigning student-created accounting video projects, and bringing in expert guest speakers or distributing lessons online via videoconferencing and lecture-capture tools. We also explain how numerous accounting professors and business schools are taking advantage of the capabilities available through digital video technologies. In addition, we introduce a newly created website that complements the teaching ideas presented in this article and that facilitates video integration into accounting courses.

Throughout our discussion, we reference the pedagogical benefits in using video as an accounting teaching tool, including those from the general education literature (viz., Bloom's Taxonomy, Fleming's Learning Styles (VARK), and Gardner's Multiple Intelligences) and from the literature of accounting education (i.e., AICPA Core Competencies Framework). The article concludes with suggestions for staying current with video technology, future research areas and a call to action for accounting educators.

\section{Observations of video in accounting education and video technology innovations}

In this section we describe present-day situations where video can enhance accounting education compared to past traditional practices and discuss significant developments in digital video technology that can be used in accounting education. 


\subsection{Then and now: the impact of video on accounting education}

In the past, it used to be the case that an accounting professor inviting a guest speaker would have to go through significant organizational efforts. Today, a professor can easily bring in a guest speaker via the internet to interact with his class, regardless of geographical or time zone differences. These "Virtual Visits" can be done for little or no cost due to video technologies.

Also in the past, it used to be the case that an accounting professor desiring to take students out of the classroom to experience a foreign culture or business environment would have to arrange a semester or a shorter intensive class in a foreign country. Such visits would include costly travel arrangements and the logistical considerations were likely very imposing. Today, with videoconferencing technology, students can be exposed to foreign cultures and business practices without the accompanying travel concerns. Leading MBA programs now have their students collaborate on cross-border projects with foreign-based peers to expose US students to an experience that will be integral to their future careers (Best, 2010; Cisco, 2010a). Videoconferencing technologies often play a critical role in such global student collaborations and communications.

Finally, in the past, an accounting professor's audience used to be the students physically present. Today, with the use of video technology, the classroom can literally be thousands or millions of students, located in many different countries. Susan Crosson, one of the founders of the AAA Conference on Teaching and Learning in Accounting (CTLA), has pioneered the use of video technology via YouTube.com to teach both financial and managerial accounting. Kevin Stocks, past President of the AAA, when awarding Professor Crosson the 2010 AAA Outstanding Service Award, stated that "her videos now have had more than 2,300,000 views and receive more than 5000 views per day" (American Accounting Association, 2010). Susan Crosson has announced plans to create another 200 online accounting videos in the forthcoming years for updates and new topics (Garrett, 2010). By late 2011, Susan Crosson had 4.7 million views on Youtube.

\subsection{Video technology innovations}

New technological innovations have led to a "renaissance" in using video communication for higher education. In the space below we discuss the more significant of these developments.

Recently, the Fuqua School of Business at Duke University unveiled the world's first "virtual classroom," integrating within a single room the Cisco Systems Telepresence with three life-sized, High Definition (HD) monitors. This enables the real-time meeting of students, professors, and guest experts in four separate locations, anywhere in the world (Cisco, 2010b). The Fuqua School of Business has also adopted Cisco "Quad," a collaboration platform for use by students and faculty in the MBA Cross-Continent program. Cisco Quad allows students located in the US, India, Russia, Dubai, England, and China to create virtual working groups, locate people with common interests, share files or videos with other students working on similar projects and instantly start video conferences or chat sessions (Lavelle, 2010). Therefore, students worldwide can fully engage in this cross-continent program at any Duke campus, not as passive listeners, but as active participants in the learning experience.

In 2011, Apple released the iPhone 4s. The iPhone application "Facetime" allows televideo conferencing in a handheld device. Furthermore, the iPhone now incorporates the capabilities of an HD camcorder and goes one step further by allowing such videos to be edited directly in the iPhone via the Apple video editor iMovie. Thus, accounting students can now shoot a video class project and perform the editing within their hands, regardless of location (Apple Inc., 2010a). The Ipad 2 (released in 2011) has similar capabilities.

Abilene Christian University started a program in which freshman students have the choice of a free iPhone or an iPod Touch, which in its latest edition also includes Facetime and an HD camcorder. The initiative's goal is to explore how these wifi-connected devices revolutionize the classroom experience. This includes watching video podcast lectures. Forty-eight percent of enrolled Abilene students and $97 \%$ of Abilene faculty have iPhones (Chen, 2009).

A new concept called "Vook" - a hybrid between a video and a book - displays videos directly next to the corresponding text. Vooks can be accessed via computers or handheld devices. In addition to the 
video, the text can include hyperlinks to updated sources or video links to livestream webcams such as the SEC or FASB Open Meetings.

Other well-known tools are vastly improved. Skype now offers 10 -way video calling, mobile videoconferencing, and the utilization of newly available Logitech HD web cameras. Skype has also developed "Skype in the Classroom" (http://education.skype.com), a free directory for teachers who want to visually connect with classrooms in other countries to exchange ideas and experience new cultures. Blackboard, the widely used learning management system (LMS), provides the videoconferencing capabilities of Wimba and Elluminate. ${ }^{2}$

Thus, it is evident that the pace of video technology innovation is rapidly accelerating and that video holds great promise for the entire academic world including accounting education. John Chambers, Chairman of Cisco, recently declared that "Video is the New Voice." It is estimated that by the year 2013 90\% of all internet traffic will be video related (Burton, 2010).

\section{Our initial exploration: online video clips in accounting education}

In this section, we discuss our initial use of video and the pedagogical benefits of using video clips in accounting education. We also illustrate the availability of digital videos for a variety of current accounting subjects and as a hands-on example show how we utilize online videos for the teaching of International Accounting courses.

\subsection{Video clips in the teaching of International Financial Reporting Standards (IFRS)}

Our first use of digital video technology in teaching accounting occurred within our International Accounting courses during the fall semester of 2008. On August 27, 2008, the Securities and Exchange Commission (SEC) announced the proposed "Roadmap for the Potential use of Financial Statements prepared in accordance with IFRS by US Issuers." Soon thereafter, a multitude of IFRS online videos and webcasts appeared on the internet. We found many of these videos engaging and up-to-date and thought they could support our students as well.

The first IFRS video we showed to our students was an 8-min video entitled "Adopting Global Standards," created by the American Institute of Certified Public Accountants (AICPA). We noticed that the students were extremely attentive and that stimulating discussions were generated by the screening. The president of the student accounting society wanted to invite an IFRS expert to address the next student meeting. A different student wanted to do her senior thesis on IFRS. This was our first experience with witnessing how video could spark student interest and engagement and how it can be used as a motivational tool for accounting students.

With such encouraging results, we sought additional IFRS videos and webcasts by conducting internet searches using key words such as "IFRS and video," "IFRS and webcast," and "IFRS and webinar." We soon had compiled a vast collection of videos and webcasts regarding the development and implementation of IFRS. We then categorized, classified and designed implementation strategies for these videos and webcasts throughout the accounting curriculum. These listings are available at www.teachingifrs.com/ifrs.html. In December of 2008, PricewaterhouseCoopers (PwC) awarded one of the authors of this manuscript an IFRS Ready Grant that supported the creation of a stand-alone IFRS course that incorporated the use of video clips and webcast excerpts into the curriculum. This course was subsequently recognized by an AICPA task force for an honorable mention for the 2009 Mark Chain/Federation of Schools of Accountancy (FSA) Innovation in Graduate Teaching Award.

\subsection{Video clips in the teaching of current and emerging accounting topics}

The internet has vast repositories of timely and relevant videos for a variety of accounting courses. The primary sources and locations of video clips include the websites of professional accounting institutes, accounting firms, universities, and video-hosting websites. These video clip supplements are

\footnotetext{
${ }^{2}$ Wimba and Elluminate provide online interactive collaboration tools that include two-way interactive video.
} 
especially valuable for current and emerging topics in accounting. In Table 1, we have compiled a list of our recommendations for insightful videos for these current topics in accounting. For easier classroom use, the authors have created a website with live accounting video links (www.teachingifrs.com) that we will be updating on a quarterly basis. This website also includes many tips for in class video display and student video projects (www.teachingifrs.com/tips.html).

Our initial use of video clips and webcast excerpts served as a supplementary tool and as a facet of instruction along with other resource material available for teaching a given topic. We feel that professors should consider using video in the classroom in a manner similar to how they consider the use of any other pedagogical tool. Learning goals should be specified, an instructional order should be established, and reinforcement activities developed.

Multiple authors suggest that video showings in class should not be longer than 5-10 min. Ellis and Childs (1999) found that students lost interest while watching 15-min video segments and recommended that shorter video clips be used. It has been noted that "students learn best from short segments that are directly related to the lesson" (Gillespie, 2007). Videos should be verbally introduced prior to screening in class in order to communicate the context and meaning for the students. Also, a discussion during the filming by using the "pause" feature or after the showing should be held in order to ensure that students absorb the relevant lessons to be taken away. Videos or webcasts of a longer duration can be assigned for out-of-class viewing.

Table 2 displays two cases of integrating online digital video clips into our Spring/2011 International Accounting graduate-level courses. This was done for the weekly topics of: (1) The Status and Outlook of IFRS Adoption in the United States; and (2) International Sustainability Accounting and Integrated Reporting. The class met once a week for $2 \frac{1}{2} \mathrm{~h}$ per session.

For the second week of the international accounting course, the learning objective is to provide students with current knowledge of the SEC IFRS adoption efforts and the IASB-FASB convergence progress. The three videos listed in Table 2 for the Week 2 Topic are shown in class in addition to a PowerPoint presentation, class discussion and review of homework assignments. These video clips emphasize and complement the goals of the session by providing an opportunity for the students to see and hear some of the major personalities involved in the efforts to implement the global standards for US companies.

Rather than just reading a book or article, the students can see and hear these "cyber-guest" lecturers bring the topic to life. Thus, in the portion of the class dealing with the introduction of the 2008 IFRS Roadmap, the video clip of former SEC Chairman Christopher Cox is inserted. Later in the class discussion, as we move into 2010 and 2011 developments, Mary Shapiro, current SEC Chairperson, is introduced with her opening remarks to the SEC Open Meeting on IFRS. Finally, in order to provide the perspective of the International Accounting Standards Board (IASB) on US developments, an interview video clip with Sir David Tweedie is inserted into the final portion of the lesson. In just a few minutes, the students have received from key decision makers a well-rounded and first-hand topical discussion of the potential adoption of IFRS in the US.

Another example of the use of video clips in the international accounting course is the topic of "Sustainability Accounting and Integrated Reporting," which is covered in Week 11 of the course. In this week, the learning objective is to enable the students to understand the what, why, and how of Sustainability Accounting. The video clips that are shown allow the students to hear and see first-hand prominent global business leaders and accountants. In the opening of the weekly lesson, the twominute video entitled "Eco-Warriors or Business Leaders" is shown to allow the students to hear from industry leaders that are endorsing the integration of sustainability accounting into their corporate reporting. This has a significant effect on students' perception of the importance of this topic, especially when hearing from the likes of Sir Richard Branson of Virgin Group and Indra Nooyi of PepsiCo. Later in the class session, the video entitled "Eco Consulting, LLC," created by students at the University of Texas (Dallas), is shown to demonstrate the value that the AICPA places upon sustainability with their 2010 Sustainability Student Video Competition and how students can create a practical solution to a real-life hotel sustainability strategy. This video clip also demonstrates how sustainability accounting can be an exercise in controlling costs. The students in our class have their attention heightened as they watch the University of Texas students analyzing an actual sustainability case. Finally, in the latter portions of this weekly lesson, our students hear and see both Sir Mark Moody- 
Table 1

Author recommended videos for current topics in accounting.

\begin{tabular}{|c|c|c|}
\hline Title & Description & Link \\
\hline \multicolumn{3}{|c|}{ International accounting (IFRS) } \\
\hline $\begin{array}{l}\text { PwC IFRS video } \\
\text { learning center }\end{array}$ & $\begin{array}{l}\text { A collection of technical IFRS } \\
\text { videos }\end{array}$ & www.pwc.com/usifrs/vlc \\
\hline $\begin{array}{l}\text { Collection of IFRS } \\
\text { videos }\end{array}$ & $\begin{array}{l}\text { AICPA's IFRS.com website } \\
\text { includes frequently updated } \\
\text { videos on IFRS }\end{array}$ & www.ifrs.com/video.html \\
\hline $\begin{array}{l}\text { Collection of IFRS and } \\
\text { other accounting } \\
\text { videos }\end{array}$ & $\begin{array}{l}\text { Well-known experts report on } \\
\text { current developments in } \\
\text { accounting, including IFRS }\end{array}$ & http://journalofaccountancy.com/Multimedia \\
\hline $\begin{array}{l}\text { Lubin School of } \\
\text { Business at Pace }\end{array}$ & $\begin{array}{l}\text { Each year, the Lubin School of } \\
\text { Business provides on the }\end{array}$ & $\begin{array}{l}\text { http://www.pace.edu/pace/lubin/news-events/lubin-forum- } \\
\text { on-contemporary-accounting-issues }\end{array}$ \\
\hline $\begin{array}{l}\text { University: Forum } \\
\text { on contemporary } \\
\text { accounting issues }\end{array}$ & $\begin{array}{l}\text { Internet videos from their } \\
\text { yearly conference, most of } \\
\text { them on IFRS }\end{array}$ & \\
\hline EY thought center & Webcasts on IFRS & http://webcast.ey.com/thoughtcenter \\
\hline \multicolumn{3}{|l|}{ Sustainability accounting } \\
\hline $\begin{array}{l}\text { Uniform reporting } \\
\text { standards? }\end{array}$ & $\begin{array}{l}\text { CNBC Interview with Paul } \\
\text { Druckman of A4S on } \\
\text { Sustainability Accounting and } \\
\text { the newly created organization } \\
\text { International Integrated } \\
\text { Reporting Committee (IIRC) }\end{array}$ & www.integratedreporting.org/node/17 \\
\hline $\begin{array}{r}\text { Sustainability } \\
\text { accounting }\end{array}$ & $\begin{array}{l}\text { HRH, The Prince of Wales, } \\
\text { addresses Accounting for } \\
\text { Sustainability to the AICPA }\end{array}$ & $\begin{array}{l}\text { http://www.journalofaccountancy.com/Multimedia/ } \\
\text { ?bcpid=1842749430\&bclid=1704093216\&bctid=44650684001 }\end{array}$ \\
\hline $\begin{array}{l}\text { Sustainability: the } \\
\text { role of CPAs in } \\
\text { business \& } \\
\text { industry }\end{array}$ & $\begin{array}{l}\text { AICPA Senior Vice President } \\
\text { Arleen Thomas explains how } \\
\text { CPAs can benefit by focusing on } \\
\text { environmentally and socially } \\
\text { responsible activities by } \\
\text { companies }\end{array}$ & $\begin{array}{l}\text { http://www.journalofaccountancy.com/Multimedia/ } \\
\text { ?bcpid=1842749430\&bclid=1704093216\&bctid=53624518001 }\end{array}$ \\
\hline $\begin{array}{l}\text { Sustainability: } \\
\text { successfully } \\
\text { implement the } \\
\text { "Triple Bottom } \\
\text { Line" }\end{array}$ & $\begin{array}{l}\text { Patricia Cochran, CFO of VSP } \\
\text { Vision Care, explains how VSP } \\
\text { Vision Care has implemented } \\
\text { sustainable business practices }\end{array}$ & $\begin{array}{l}\text { http://www.journalofaccountancy.com/Multimedia/ } \\
\text { ?bcpid=1842749430\&bclid=1704093216\&bctid }=61007647001\end{array}$ \\
\hline $\begin{array}{l}\text { Launching } \\
\text { sustainability } \\
\text { services }\end{array}$ & $\begin{array}{l}\text { Michael Knowles of Frank, } \\
\text { Rimerman \& Co, LLP, explains } \\
\text { how his firm began consulting } \\
\text { on the measurement of } \\
\text { sustainable activities }\end{array}$ & $\begin{array}{l}\text { http://www.journalofaccountancy.com/Multimedia/ } \\
\text { SustainabilityServices }\end{array}$ \\
\hline \multicolumn{3}{|l|}{ Forensic accounting } \\
\hline $\begin{array}{l}\text { Fraud and the tone at } \\
\text { the top }\end{array}$ & $\begin{array}{l}\text { The AICPA and ACFE joined } \\
\text { forces to produce this training } \\
\text { video on the influence top } \\
\text { management has on fraud } \\
\text { prevention }\end{array}$ & $\begin{array}{l}\text { http://www.acfe.com/video/VideoBox.asp?Video=tone-at-the- } \\
\text { top }\end{array}$ \\
\hline The man who knew & $\begin{array}{l}\text { CBS } 60 \text { Minutes interviews } \\
\text { Harry Markopolos who } \\
\text { repeatedly wrote to the SEC } \\
\text { that Madoff's investment fund } \\
\text { was a fraud }\end{array}$ & www.youtube.com/watch?v=s68FR1MXT8Q \\
\hline $\begin{array}{l}\text { It takes one to know } \\
\text { one }\end{array}$ & $\begin{array}{l}\text { Former Conman Barry Minkow } \\
\text { of ZZZZ Best describes how he } \\
\text { committed fraud and how he is } \\
\text { now using his old "skills" to } \\
\text { help detect fraud }\end{array}$ & www.youtube.com/watch?v=JydqCyFsmS8 \\
\hline $\begin{array}{l}\text { The big lie: Inside the } \\
\text { rise and fraud of }\end{array}$ & $\begin{array}{l}\text { CNBC reports on how Bernard } \\
\text { Ebbers and the fraud at }\end{array}$ & $\begin{array}{l}\text { http://video.google.com/ } \\
\text { videoplay?docid=6560803301631269691\# }\end{array}$ \\
\hline
\end{tabular}

(continued on next page) 
Table 1 (continued)

\begin{tabular}{|c|c|c|}
\hline Title & Description & Link \\
\hline WorldCom & $\begin{array}{l}\text { WorldCom disrupted the } \\
\text { telecommunications industry }\end{array}$ & \\
\hline Video repository & $\begin{array}{l}\text { A website that lists dozens of } \\
\text { fraud- related videos }\end{array}$ & www.theprosandthecons.com \\
\hline \multicolumn{3}{|c|}{ eXtensible Business Reporting Language (XBRL) } \\
\hline $\begin{array}{l}\text { XBRL: The what, why, } \\
\text { and who }\end{array}$ & $\begin{array}{l}\text { In this webcast Charlie } \\
\text { Hoffman and Steve Levine } \\
\text { introduce XBRL and answer } \\
\text { questions }\end{array}$ & http://www.youtube.com/watch?v=MW-L8evKD2Y \\
\hline $\mathrm{XBRL}$ in plain English & $\begin{array}{l}\text { An animation that explains the } \\
\text { basics of XBRL }\end{array}$ & http://www.youtube.com/watch?v=5F1E-2LkhW8 \\
\hline $\begin{array}{l}\text { Christopher Cox } \\
\text { explains XBRL }\end{array}$ & $\begin{array}{l}\text { Former SEC Chairman } \\
\text { Christopher Cox explains XBRL }\end{array}$ & http://www.youtube.com/watch?v=oYaLeXowl5A \\
\hline XBRL demonstration & $\begin{array}{l}\text { XBRL Company Altova } \\
\text { demonstrates how to use XBRL }\end{array}$ & http://www.youtube.com/watch?v=y_IQT-zEq84 \\
\hline SEC XBRL trailer & SEC Employees explain XBRL & http://www.youtube.com/watch?v=1 LmgBjZgj5A \\
\hline FASB codification & . & \\
\hline $\begin{array}{l}\text { FASB accounting } \\
\text { codification } \\
\text { project }\end{array}$ & $\begin{array}{l}\text { Resources global professional } \\
\text { employee Lynn Horowitz } \\
\text { explains the codification } \\
\text { project }\end{array}$ & http://www.youtube.com/watch?v=4_keOGFMen8 \\
\hline FASB codification 1 & $\begin{array}{l}\text { Jeff Sailor, CPA, explains the } \\
\text { codification project }\end{array}$ & http://www.youtube.com/watch?v=ILNPUDUWkSg \\
\hline FASB codification 2 & $\begin{array}{l}\text { Jeff Sailor, CPA, continues his } \\
\text { explanation of the codification }\end{array}$ & http://www.youtube.com/watch?v=h4jbdda0cnM \\
\hline $\begin{array}{l}\text { FASB codification } \\
\text { update }\end{array}$ & $\begin{array}{l}\text { Thomas Hoey, CPA, FASB } \\
\text { codification project director, } \\
\text { discusses the codification } \\
\text { project }\end{array}$ & http://www.viddler.com/explore/FICPA/videos/1 \\
\hline $\begin{array}{l}\text { FASB accounting } \\
\text { standards } \\
\text { codification }\end{array}$ & $\begin{array}{l}\text { Arlene Thomas, CPA and Senior } \\
\text { V.P. of the AICPA, discusses the } \\
\text { FASB Codification }\end{array}$ & $\begin{array}{l}\text { http://www.journalofaccountancy.com/Multimedia/ } \\
\text { ?bcpid=1842749430\&bclid=1704093216\&bctid=22786846001 }\end{array}$ \\
\hline
\end{tabular}

Table 2

Illustrations of video clip classroom integration for international accounting (Spring, 2011).

\begin{tabular}{|c|c|c|}
\hline Video clip title and expert/participants & $\begin{array}{l}\text { Clip } \\
\text { duration }\end{array}$ & Video clip URL \\
\hline \multicolumn{3}{|c|}{ Week 2 topic: The status and outlook of IFRS adoption in the United States } \\
\hline SEC Chairman Christopher Cox: Comments on IFRS (2008) & $8 \mathrm{~min}$ & http://bcove.me/gjx5jywe \\
\hline $\begin{array}{l}\text { SEC Chairperson Schapiro's opening statement at open } \\
\text { meeting on global accounting standards (2010) }\end{array}$ & $4 \mathrm{~min}$ & http://youtu.be/1Pf4Q6F8cEw \\
\hline $\begin{array}{l}\text { IASB Chairman Sir David Tweedie, Interviewed by Henry } \\
\text { Keizer, Head of Global Audit for KPMG (2010) }\end{array}$ & $7 \mathrm{~min}$ & $\begin{array}{l}\text { http://www.kpmginstitutes.com/ifrs- } \\
\text { institute/events/live-interview-with-sir- } \\
\text { david-tweedie.aspx }\end{array}$ \\
\hline \multicolumn{3}{|l|}{ Week 11 topic: Sustainability accounting and integrated reporting } \\
\hline Eco-warriors or business leaders (2011) & $2 \min$ & $\begin{array}{l}\text { http://www.accountingforsustainability.org/ } \\
\text { output/Page194.asp }\end{array}$ \\
\hline \multicolumn{3}{|l|}{$\begin{array}{l}\text { Sir Richard Branson of Virgin Group, Indra Nooyi of PepsiCo, } \\
\text { Stuart Rose of Mark \& Spencer }\end{array}$} \\
\hline $\begin{array}{l}\text { Eco Consulting, LLC (2010). Winning video created by } \\
\text { students at the University of Texas-Dallas for the } 2010 \\
\text { AICPA Student Accounting Video Competition }\end{array}$ & $6 \mathrm{~min}$ & http://youtu.be/fa9zFi3Wqc4 \\
\hline $\begin{array}{l}\text { Why Integrated Reporting (2011). Sir Mark Moody-Stuart, } \\
\text { IIRC Member, Beijing }\end{array}$ & $6 \mathrm{~min}$ & http://youtu.be/dyEC_co1fDw \\
\hline $\begin{array}{l}\text { Launching Sustainability Service (2010). Michael Knowles, } \\
\text { Partner at Frank, Rimerman \& Co LLP, on sustainability } \\
\text { consulting for clients }\end{array}$ & $5 \mathrm{~min}$ & http://bcove.me/z8tsg8m3 \\
\hline
\end{tabular}


Stuart, a member of the International Integrated Reporting Committee (IIRC), explain the concept of integrated reporting, and Michael Knowles, Partner at Frank, Rimerman \& Co LLP, on how his firm is now offering client services related to sustainability consulting. These latter two videos are used to open student eyes to the growing opportunities and importance to accounting career development of becoming proficient in the issues of sustainability reporting.

Accounting professors are already using online videos and webcasts to supplement their accounting course content. Mike Meyer from the University of Notre Dame conducts searches on the internet in order to find and share video clips that give his students an understanding of business environments that they are unfamiliar with. At the 2011 AAA-Midwest Region meeting, Meyer shared an online video that demonstrated how a RFID (Radio Frequency Identification) technology can enhance a firm's control environment (David, 2011b). Rick Lillie of California State University, San Bernardino, uses webcasts produced by CPE Link, a web-based CPE provider, to supplement three audit-related courses. These webcasts entitled "Understanding Assertions," "Types of Tests," and "Understanding Internal Control," focus on areas Professor Lillie says are particularly challenging for accounting students to master. "I'm pleased to be able to incorporate these webcasts into my courses because they provide to students on a 24/7 basis an additional way to learn very challenging material" said Dr. Lillie. Sue Anderson, CPE Link Program Director, stated: "We hope this arrangement will enrich the academic curriculum and become a model that other colleges and universities will follow" (CPE Link, 2010).

\subsection{Benefits of using video clips in accounting education}

Based upon numerous positive comments that we have received from course evaluations over the past three years, we are confident that students find value in the use of short video clips and webcast excerpts. Watching and listening to renowned experts underlines the importance and credibility of the content and helps students to memorize key concepts by linking these concepts to the experience of watching a specific video.

Neil Fleming is the innovator of the well-known questionnaire entitled VARK (which stands for

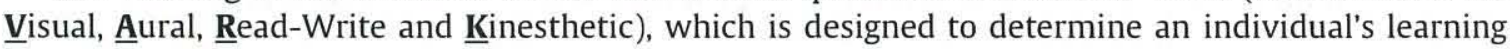
style. The VARK model shows that learning depends on how receptive individuals are to applied learning styles (Fleming, 1995). While traditional higher education benefits Aural and Read/Write learners, video clips and projects provide an opportunity to better engage Aural/Visual and Kinesthetic learners. Video transmits information through both aural and visual senses at the same time. Thus, video allows students to have multiple entry points into the learning material (Gardner, 2006).

Video has additional benefits compared to providing information solely through textbooks. While textbooks use mainly a linguistic format, videos use a variety of modes, therefore meeting the needs of a wider spectrum of students. A recent study found that learners of business content prefer video to text and also find video content more engaging than text (Hedge, Useem, \& Martinez, 2011).

The Corporation for Public Broadcasting (CPB) funded a study (CPB, 2004) that reviewed educational surveys and research and concluded that educational video:

- Reinforces reading and lecture material.

- Enhances student comprehension and discussion.

- Provides greater accommodation of diverse learning styles.

- Increases student motivation and enthusiasm.

- Promotes teacher effectiveness.

One of video's best features is the capability to communicate on both emotional and cognitive levels. By reaching viewers emotions, video can strongly impact both motivation and affective learning. Well-selected video has the ability to engage students, stimulate strong interest in a topic, activate emotional states, and facilitate in the absorption and processing of information (Marshall, 2002).

From a professor's perspective, there are also practical and logistical benefits in using video clips or webcast excerpts. As noted earlier, the process of locating and bringing in expert speakers is facilitated via video, which is particularly valuable for faculty located in remote areas. This is exemplified by 
the innovative "BridgeIT" program (www.iyfnet.org/bridgeit) in developing nations, which enables teachers to download educational videos to rural classrooms via a cell-phone-distribution infrastructure (Erumi, 2010).

An additional benefit of video clip usage for a professor is the enlivening of a lecture or class discussion by the insertion of a real-world perspective. In this context, the timeliness of online video clearly outperforms traditional teaching material. Online videos are typically available quickly after important speeches or events take place. Similar to current newspaper articles, online video can fill in the timing gap prevalent in textbook creation and can provide up to date knowledge to the classroom.

Thus, a lesson plan that includes video helps students with diverse learning styles to comprehend concepts and to retain information. Video also increases enthusiasm about the information presented and improves motivation to learn. Video provides a learning experience that engages students in ways beyond traditional textbook and lecture. It can also be an effective tool to point out the relevance of a topic.

Table 3

Summary of the major educational/pedagogical benefits of video technology in the classroom.

\begin{tabular}{l}
\hline Educational/pedagogical benefits \\
1. Video clips and projects provide an opportunity to better \\
engage Aural/Visual and Kinesthetic Learners \\
2. Video transmits information through both aural and \\
visual senses at the same time. Thus, video allows \\
students to have multiple entry points into the learning \\
material \\
3. Learners of business content prefer video to text and also \\
find video content more engaging than text
\end{tabular}

4. Educational video:

- Reinforces reading and lecture material

- Enhances student comprehension and discussion

- Provides greater accommodation of diverse learning styles

- Increases student motivation and enthusiasm

- Promotes teacher effectiveness

5. Video has the capability to communicate on both emotional and cognitive levels. By reaching viewers emotions, video can strongly impact both motivation and affective learning

6. The process of locating and bringing in expert speakers is greatly facilitated via video, which is particularly valuable for faculty located in remote areas

7. According to Bloom's Digital Taxonomy Map, a modern day interpretation of Bloom's original taxonomy, the creation of video involves the highest-order thinking skills. Video projects include the actions of understanding, planning filming, directing, creating, combining and media publishing on the web

8. Video projects for students involve multiple AICPA Core Competencies.

\section{Source}

Fleming, N. D. (1995). I'm different, not dumb. Modes of presentation (VARK) in the tertiary classroom. In: Zelmer, A. (Ed.), Research and development in higher education, proceedings of the 1995 annual conference of the higher education and research development society of australasia (HERDSA) (Vol. 18, pp. 308-313)

Gardner, H. (2006). Multiple intelligences. New Horizons. New York: Basic Books

Hedge, S., Useem, A., \& Martinez, S. (2011). Engaging with business learning: The source and medium do matter, Whitepaper prepared for Big Think, May 25, 2011, retrieved on June 18, 2011, <http://assets.bigthink.com/ WhitePaperv1.pdf.>

Corporation for Public Broadcasting (2004). Television Goes to School: The Impact of Video on Student Learning in Formal Education, retrieved on August 20, 2011, from http://www.dcmp.org/caai/nadh173.pdf

Marshall, J.M. (2002). Learning with technology: Evidence that technology can, and does, support learning. White paper prepared for Cable in the Classroom by Dr. James M. Marshall, a member of the Department of Educational Technology at San Diego State University Erumi, T. R. (2010). Bridgeit: Empowering Teachers with Video via Mobile Phones, retrieved on December 22, 2010, from http://edutechdebate.org/meducation-initiatives/ bridgeit-empowering-teachers-with-video-via-mobilephones

Churches, A. (2008). Bloom's Taxonomy Blooms Digitally, retrieved on September 14, 2011, from http:// www.techlearning.com/article/blooms-taxonomy-bloomsdigitally/44988

http://aicpa.org/interestareas/accountingeducation/ resources/pages/corecompetency.aspx 
Some areas are difficult to properly provide to students without video. In a forensic accounting course, the discussion of the importance of body language in interrogations and depositions can be best and most efficiently demonstrated through available training videos. In an accounting information systems (AIS) class, the importance of physical security can be explained orally, but such an explanation is inferior to observing via video how different types of locks can be surpassed within a matter of seconds. Table 3 summarizes the major educational benefits of using video in the classroom.

Nevertheless, despite the advantages of utilizing expert videos, there still exists an absence of personal interaction between the students and the guest speakers on the screen. Thus, we set forth to investigate how more interaction could be created between the students and the experts.

\section{Our subsequent use of video technology: student-created videos and distance communication via teleconferencing and Skype}

In this section, we share our own experiences with student-created videos, as well as describe similar student video programs/assignments of accounting institutes and professors that have arisen. We conclude this section with a discussion of the benefits of student-created video projects and assignments.

\subsection{Our video project to connect students to experts}

To overcome the lack of interaction with the accounting experts appearing on video clips or webcast excerpts, we experimented with a new video assignment. We designed and implemented a student-created video project in both of our International Accounting courses at the graduate level. This project has been reported in detail along with assessment data in Holtzblatt and Tschakert (2011); a summary of this project is listed below.

One of our priorities in terms of this follow-up project was to inject and maintain a high level of academic rigor. The project was a group undertaking involving three students per group. We established a variety of IFRS topics that were assigned to the students. Upon receiving their topic, the student groups had to utilize project management principles to plan their tasks, divide student responsibilities, and draft timelines for the group. At the end of the semester, the students were to turn in a video of approximately 5-15 min, involving interviews with IFRS experts.

Each of the two supervising professors provided student teams with four complete sets of selffunded camcorder equipment that included the Kodak Zi8 camcorder. These sets were used to film experts such as Sue Haka (Michigan State University, and former AAA president), Belverd Needles (DePaul University), and Kenneth Marshall (Senior Partner, Ernst \& Young and EY IFRS Leader, New York City).

The long-distance interviews, both interstate and international, were conducted with either the university Cisco and Polycom systems or web-based tools including Skype and Windows Live Messenger. Our students were able to interview IASB members, including Sir David Tweedie, located in the UK, and Paul Pacter, located in Hong Kong. In the US, our students interviewed via teleconference PCAOB board member Charlie Niemeier, NASBA President David Costello, IASB Standard Advisory Council Member Jerry de St. Paer, and FASB Fellow Jeffrey Hales. The best of these student-created videos are now available at www.vimeo.com/IFRS and can be shown in class or assigned for self-study. For our efforts regarding our student video project, we were awarded the 2011 AAA Innovation in Accounting Education Award and the 2010 CAAA Howard Teall Innovation in Accounting Education Award.

We observed multiple benefits from our student video project. The following summary data shows that students valued the opportunity to interact with accounting professionals and appreciated the opportunity to learn new technological skills and tools for online communication. On a scale of 1 (very much) to 6 (not at all), the 48 participating students stated that the project improved their expertise in the topic (2.56), allowed them to interact with accounting professionals (2.33), improved their 
Table 4

AICPA core competencies in our IFRS student video project.

\begin{tabular}{|c|c|}
\hline AICPA core competencies & Our students applying the AICPA core competencies \\
\hline \multicolumn{2}{|l|}{ 1. Functional competencies } \\
\hline Reporting & $\begin{array}{l}\text { Students considered various alternative methods to report their findings via } \\
\text { PowerPoint and other technology tools }\end{array}$ \\
\hline Research & $\begin{array}{l}\text { Students had to research IFRS issues from many different sources in } \\
\text { preparation for interviewing IFRS experts }\end{array}$ \\
\hline $\begin{array}{l}\text { Leverage technology to develop and } \\
\text { enhance functional competencies }\end{array}$ & $\begin{array}{l}\text { Students learned and utilized numerous technological tools for researching } \\
\text { their IFRS topics, communicating with IFRS experts, and for recording and } \\
\text { editing the interviews }\end{array}$ \\
\hline \multicolumn{2}{|l|}{ 2. Personal competencies } \\
\hline Professional demeanor & $\begin{array}{l}\text { Students learned how to effectively communicate with executives and were } \\
\text { able to experience how to interact and present themselves in the corporate } \\
\text { environment }\end{array}$ \\
\hline Problem solving and decision making & $\begin{array}{l}\text { Students displayed effective problem solving and decision-making skills, as } \\
\text { well as innovative and creative thinking }\end{array}$ \\
\hline Interaction & $\begin{array}{l}\text { Students worked as a team to accomplish assigned objectives. Students also } \\
\text { assumed different roles }\end{array}$ \\
\hline Leadership & $\begin{array}{l}\text { Students inspired and motivated their team to achieve the common } \\
\text { objectives of the group }\end{array}$ \\
\hline Communication & $\begin{array}{l}\text { Students exercised their ability to listen and learned how to deliver } \\
\text { powerful presentations }\end{array}$ \\
\hline Project management & $\begin{array}{l}\text { Students demonstrated the ability to control the course of a multi- } \\
\text { dimensional, multi-step undertaking }\end{array}$ \\
\hline $\begin{array}{l}\text { Leverage technology to develop and } \\
\text { enhance personal competencies }\end{array}$ & $\begin{array}{l}\text { Students adapted to new technologies, acquired new skills and determined } \\
\text { how new technologies could be incorporated into their projects }\end{array}$ \\
\hline 3. Broad business perspective competencies & f \\
\hline $\begin{array}{l}\text { International/global perspective } \\
\text { competencies }\end{array}$ & $\begin{array}{l}\text { Students identified and communicated various threats and opportunities } \\
\text { related to a potential adoption of IFRS in the US }\end{array}$ \\
\hline
\end{tabular}

technological skills and use of online communication (2.5) and improved their project and selforganizational skills (2.9) (Holtzblatt \& Tschakert, 2011).

Numerous AICPA Core Competencies ${ }^{3}$ were addressed and exercised throughout our IFRS student video project. Table 4 provides the details of the Core Competencies and how each was exercised during the conduct of the student projects:

In a recent RMIT University (Australia) study, "A Programme to Expose Students to Senior Executives in the World of Accounting: An Innovative Learning Method" (Webb, De Lange \& O'Connell, 2009), the authors expressed the view that a likely criticism was that, due to its cost, only "rich" students could participate in their International Study Tour (IST). Based on our student video project experience, videoconferencing and communication tools such as Skype provide the opportunity to all students, regardless of their financial background, to interact with accounting professionals throughout the world.

The University of Southern California (USC) Leventhal School of Accounting provides another example of such communication tools in facilitating valuable international interactions for students. In the Spring, 2010 semester, accounting seniors, led by Professor Cecil Jackson, worked on a crosscontinental collaboration project, using Skype, with a corresponding team from the Chinese University of Hong Kong (CUHK) on a case written by Professor Ken Merchant. Dean Randolph P. Beatty stated: "This educational innovation is building a possible four-year global immersion experience for our students while working from the Accounting Library or from home ... and that's pretty amazing" (USC, 2010). The specific pedagogical elements of the 2010 USC-CUHK use of Skype are described in Table 5 (Beatty, 2011).

\footnotetext{
${ }^{3}$ A full description of the AICPA Core Competencies is available at http://aicpa.org/interestareas/accountingeducation/resources/ pages/corecompetency.aspx.
} 
Table 5

2010 case-study collaboration: USC \& CUHK.

\begin{tabular}{ll}
\hline $\begin{array}{l}\text { Project } \\
\text { criteria }\end{array}$ & Project description \\
\hline Outline & $\begin{array}{l}\text { A USC Leventhal School of Accounting team collaborates with a team from the Chinese University of Hong } \\
\text { Kong (CUHK) to solve a case: Las Ferreterias de Mexico, S.A. de C.V. The USC and CUHK teams jointly write } \\
\text { reports } \\
\text { (1) Encourage students to study an issue in managerial accounting control systems with cross-cultural } \\
\text { influences; (2) Give students experience in using video-conferencing for synchronous virtual collaboration } \\
\text { The collaboration must include a video-conference session, as well as an audio or an audio and video } \\
\text { recording of this session (10 min minimum) }\end{array}$ \\
An audio and/ or visual recording of 10 min of the video conference session \\
\hline Deliverables
\end{tabular}

\subsection{The recent emergence of student video programs in accounting education}

\subsubsection{Accounting institute and society-sponsored student video programs}

Various accounting organizations throughout the world now conduct and sponsor student programs involving the creation of video. In 2010, the AICPA initiated an annual national undergraduate case competition in which students are required to create and submit a video of their case solution. The 2010 competition focused on how the Umstead Hotel and Spa could improve its sustainability (American Institute of Certified Public Accountants (AICPA), 2010). The winning student video is available at http://youtu.be/fa9zFi3Wqc4. For 2011, the AICPA student case competition will require a video on the topic of Fraud and Forensic Accounting. An AICPA video introducing the 2011 competition to university accounting faculty is available at http://youtu.be/VewjM9ETOnQ.

The Institute of Management Accountants (IMA) conducts the annual IMA Case Competition, in which students from universities across the globe can participate. A managerial accounting student case study is published each year in the August issue of Strategic Finance and each student team must address the requirements of the case in a video presentation, which is then viewed and rated by a panel of faculty judges.

Additional accounting institutes throughout the world have integrated a video component into various annually-held student programs. Table 6 summarizes programs known to us as of the date of this writing.

\subsubsection{University professor-assigned student video projects}

Student video projects/assignments supervised by accounting professors are beginning to surface and we have noticed an increase in the posting of such projects online. Excellent work was done by

Table 6

Annual accounting institute \& society student accounting programs requiring video.

\begin{tabular}{|c|c|c|}
\hline Organization & Title & Description \\
\hline $\begin{array}{l}\text { American Institute of Certified } \\
\text { Public Accountants (AICPA) }\end{array}$ & $\begin{array}{l}\text { AICPA accounting } \\
\text { competition }\end{array}$ & $\begin{array}{l}\text { Students analyze topics that vary each year with videos } \\
\text { being submitted in the latter competition rounds }\end{array}$ \\
\hline Beta Alpha PSI/KPMG & Gold challenge & $\begin{array}{l}\text { BAP chapters explain in videos why they are the best } \\
\text { chapters }\end{array}$ \\
\hline $\begin{array}{l}\text { Chartered Institute of } \\
\text { Management Accountants } \\
\text { (CIMA) }\end{array}$ & $\begin{array}{l}\text { CIMA global business } \\
\text { challenge }\end{array}$ & $\begin{array}{l}\text { Students analyze a case study and create a video for } \\
\text { CIMA's Facebook page }\end{array}$ \\
\hline $\begin{array}{l}\text { Institute of Chartered } \\
\text { Accountants in Australia }\end{array}$ & $\begin{array}{l}\text { Chartered Accountants } \\
\text { First Year Student } \\
\text { Challenge }\end{array}$ & $\begin{array}{l}\text { Students solve a real-life business problem and submit a } \\
\text { video solution }\end{array}$ \\
\hline $\begin{array}{l}\text { Institute of Chartered } \\
\text { Accountants of Ontario } \\
\text { (ICAO) }\end{array}$ & ICAO rule the tube & Students create videos on themes that vary each year \\
\hline $\begin{array}{l}\text { Institute of Management } \\
\text { Accountants (IMA) }\end{array}$ & $\begin{array}{l}\text { IMA student case } \\
\text { competition }\end{array}$ & $\begin{array}{l}\text { Students submit a video solving a case published in } \\
\text { Strategic Finance }\end{array}$ \\
\hline
\end{tabular}


students at the University of Illinois, who participated in creating three videos on "the importance of being independent," including interviews with (former) Department Head Ira Solomon (http://vimeo.com/5479009). Paulette Tandy, Professor and Chair of the Accounting Department at the University of Nevada, Las Vegas (UNLV), assigned a student group video project for the purpose of describing the various employment opportunities available to accounting majors. Several of Tandy's student groups interviewed experts in the community, a task that reportedly improved students' networking skills. Yaneli Cruz of the Instituto Tecnologico Autonomo de Mexico (ITAM) was inspired by our CTLA Master Class and now assigns student video projects involving experts. Her student groups made on-site visits to Mexican corporations to discuss and research corporate accounting practices. Visited companies include KPMG, Nestle, IBM, Wal-Mart, and HBSC. Cruz's student groups are required to document their findings in a video that is turned in for grading. Cruz does not provide any video equipment and encourages the use of any student accessible equipment including video-recording smartphones.

Student video assignments do not necessarily require interviews with experts. Video projects that involve only student participation can be assigned. A video project could be assigned in lieu of a term paper or a group PowerPoint presentation. For example, Dr. L. Murphy Smith of Texas A\&M University assigns a role-playing and country study video presentation in which teams of 6-10 students develop an 8-10 min presentation based on characters, concepts or situations related to International Accounting. Murphy grades each video and the class views and evaluates each video for originality, creativity, drama/humor, technical accuracy, and educational merit. Murphy states on his course syllabus that "the presentation should stimulate interest in the subject matter through a more captivating format than a simple lecture" (Smith, 2011). Nancy Jones of California State University-Chico, also initiated student-only video projects for her undergraduate Managerial Accounting class. Jones assigns a team research project in which students can use YouTube along with other online information sources and then create a video presentation of the research to allow Jones to view their presentation virtually as a group (Jones, 2010).

James Ziegler of Bowling Green State University integrates student-created YouTube videos into his CAPSIM course. Ziegler assigns student group video projects and students upload 5-min videos to YouTube by the end of the semester. Ziegler's group video project assignment accounts for $12 \%$ of the CAPSIM Foundation Simulation point distribution.

Table 7 summarizes a selection of student video projects assigned within the last two years in university accounting courses.

Various universities are adding video creation to a list of basic competencies students should obtain before graduation. Susan E. Metros, Associate Vice-Provost and Associate CIO for Technology Enhanced Learning at the University of Southern California, has stated: "We want all of our students that graduate from USC to have a signature experience that includes multimedia." At USC, officials have set up the "Institute for Multimedia Literacy" where non-film majors can get support for making

Table 7

Selected 2009-2011 university student accounting video projects/assignments.

\begin{tabular}{|c|c|}
\hline University (professor) & Nature of video project/assignment \\
\hline University of Illinois (Ira Solomon) & $\begin{array}{l}\text { A three-part video series on the importance of Auditor Independence that } \\
\text { included student participation }\end{array}$ \\
\hline $\begin{array}{l}\text { University of Nevada, Las Vegas } \\
\text { (Paulette Tandy) }\end{array}$ & $\begin{array}{l}\text { Student groups had to research and report via video on various career paths } \\
\text { available to accounting majors }\end{array}$ \\
\hline $\begin{array}{l}\text { Texas A \& M University (L. Murphy } \\
\text { Smith) }\end{array}$ & $\begin{array}{l}\text { Student groups had to create role-playing videos in both Dr. Smith's } \\
\text { International Accounting and Ethics courses }\end{array}$ \\
\hline $\begin{array}{l}\text { Bowling Green State University (James } \\
\text { Ziegler) }\end{array}$ & $\begin{array}{l}\text { Student groups create a video about their team's experience in making } \\
\text { decisions for their company in the CAPSIM simulation }\end{array}$ \\
\hline $\begin{array}{l}\text { Instituto Tecnologico Autonomo de } \\
\text { Mexico (ITAM) (Yaneli Cruz) }\end{array}$ & $\begin{array}{l}\text { Student groups had to visit Mexican companies to research and to report via } \\
\text { video on accounting practices }\end{array}$ \\
\hline $\begin{array}{l}\text { California State University - Chico } \\
\text { (Nancy Jones) }\end{array}$ & $\begin{array}{l}\text { Students in Managerial Accounting conduct research projects and create group } \\
\text { videos for virtual presentation }\end{array}$ \\
\hline $\begin{array}{l}\text { University of Southern California (Zivia } \\
\text { Wilson Sweeney) }\end{array}$ & $\begin{array}{l}\text { Students in the Accounting I course create video projects on various } \\
\text { accounting issues and companies }\end{array}$ \\
\hline
\end{tabular}


videos for classes they are taking. The University of Cincinnati has revised its statement of "general education core competencies" to include "oral and visual communication" in addition to writing skills. Video projects are an option in attaining that goal. The Association of College and Research Libraries recently drafted visual-literacy standards that include a call to encourage students to "design and create meaningful images and visual media (Young, 2011)."

\subsection{Benefits of student video projects/programs in accounting education}

There is an aspect of creating a video that empowers students. As we observed during our IFRS student video project, students recognize that their videos can be easily shared (in our case via a Vimeo.com website). Therefore, students put more emphasis on filming and editing a video that is of high quality. An audience of only the professor appears to be less demanding than an audience of students' peers. Students soon learn that creating a good video is a process that involves many skills such as described in Table 8 (Carver, Lehrer, Connell, \& Erickson, 1992).

According to Bloom's Digital Taxonomy map, a modern day interpretation of Bloom's original Taxonomy, the creation of video involves the highest-order thinking skills (Churches, 2008). Video projects include the actions of understanding, planning, filming, directing, creating, combining, and media publishing on the web.

The meaning of "literacy" might have to be redefined in a world of accelerating information and communication technologies (Jones-Kavalier \& Flannigan, 2006). What are the skills that students require to deal with and understand information in a world that is not based solely on print as a method of communication? Tom Hood, CPA and the CEO of the Maryland Association of CPAs (MACPA) and the founder of CPA Island in Second Life, has been a strong proponent of the accounting profession utilizing social media of all forms, including video creation. Hood was excited when he learned about our innovative teaching methods and joined us for a panel at a recent Chicago MBAA conference via video in Second Life (Hood, 2010).

Our prediction is that skills that students must learn and exercise to create a video project are increasingly in alignment with the creative and analytical skills necessary for professional employment. Many organizations are embracing video and are now encouraging and leveraging employeegenerated video content to improve innovation, collaboration, and knowledge sharing. Wells Fargo, Microsoft, and IBM have already established such video content systems. With the development of "YouTube for the Enterprise," employees can share videos on an individual, group, or company-wide basis (Schumacher-Rasmussen, 2011).

At the 2011 World Economic Forum in Davos, Alcatel-Lucent CEO Ben Verwaayen stated (Saini, 2011):

Innovation is going to be led by video and many companies are not prepared to capitalize on its power. Everywhere around you people have smart phones and they do something with it that has an element of video. Video becomes integrated in many different business models; sooner or later all companies, regardless of industry, will need to find creative ways to incorporate video into

Table 8

Observed skills involved in student video creation.

\begin{tabular}{ll}
\hline Observed skill & Description \\
\hline $\begin{array}{c}\text { Project } \\
\text { management } \\
\text { skills } \\
\text { Research skills }\end{array}$ & $\begin{array}{l}\text { Timeline creation for the completion of the project; allocating resources and time to different parts } \\
\text { of the project; assigning roles to team members }\end{array}$ \\
$\begin{array}{c}\text { Representation } \\
\text { skills }\end{array}$ & $\begin{array}{l}\text { Ascertaining the nature of the topic and the best way research should be organized; Conducting } \\
\text { searches for information using online and text-based resources } \\
\text { Choosing how to divide and order information for optimal understanding; choosing how the } \\
\text { information will be represented (video, audio, text, pictures, etc.); choosing how the information } \\
\text { will be organized and linked } \\
\text { Mapping the design onto the presentation and implementing ideas into the creation of a video; } \\
\text { attracting and maintaining the interest of the audience }\end{array}$ \\
\hline
\end{tabular}


marketing, sharing of information, communication, and learning. Those companies that are unable to cater to different audiences via various media will suffer. It's not just the phone industry or the media industry. It is going to be incorporated into every business model you find around the globe.

Furthermore, beyond acquiring useful skills for employment, video projects can be an effective way to promote active learning, as the students are put in charge and transformed into creators.

\section{Our future: video technologies to distribute accounting lessons beyond the classroom walls}

Having utilized videos created by third parties and having innovated and supervised a student-created video project, we now plan on creating our own series of digital online accounting videos for a global audience. We are currently surveying and examining the numerous video technologies available for extending the geographical reach of an accounting lecture or lesson and the various ways that accounting professors have been creating their own videos. These include synchronous and asynchronous methods.

Synchronous learning occurs when people are communicating in real time. Being in a classroom, talking in a telephone conversation, or communicating through instant messaging illustrates synchronous communication.

Asynchronous learning is more flexible. The teaching occurs at one time and is saved for the student to engage in the course at his or her convenience. Examples of asynchronous communication include email, e-courses, online forums, audio podcasts, and video recordings.

Below we examine in more detail the use of both synchronous and asynchronous video technology that can be applied to accounting education.

\subsection{Live broadcasting of classroom activities (synchronous video)}

A pioneering internet company that enables accounting professors and students to broadcast live events or classroom activities is Ustream. Ustream empowers everyone from sports fans to presidential candidates and rock stars to quickly and easily broadcast to a global audience of unlimited size. Ustream even offers a mobile application that allows broadcasting via mobile devices such as the iPhone. Two-way interactive communication is offered via the feature of live chat, which enables students to post questions, share URLs, and initiate synchronous conversations with one another. Ustream's archiving features also allow faculty to keep a record of their lectures or student presentations, offering a valuable tool for review at a later date. The Ustream services are free and simply require the use of a webcam and an internet connection.

India provides an excellent case study of the power of synchronous video-enabled teaching as applied to accounting education. The NIIT Imperia Centre for Advanced Learning (www.niitimperia.com) offers executive management programs directly from the most prestigious educational institutions in the country. At the core of NIIT Imperia's educational delivery methodology is a state-of-the-art synchronous learning technology. Institute teachers are linked to multiple remote classrooms via dedicated broadband, resulting in very reliable connections. The technology permits full features of face-to-face teaching: from a raised hand seeking the teacher's attention to tabulation of responses to quizzes created by the teacher. NIIT Imperia Education Centers are located in 19 cities, including Delhi, Mumbai, Kolkata, and Bangalore.

Since November, 2009, KPMG in India and NIIT Imperia have been collaborating to teach the Advanced Certificate Program on IFRS (KPMG, 2009). The program involves KPMG's senior professionals using NIIT's virtual classroom format to deliver the training. Through this alliance, IFRS training is offered in 19 cities simultaneously, thus helping professionals overcome the challenges of mobility and time to commute while gaining from the insights of KPMG's professionals.

\subsection{Recorded video distribution (asynchronous video)}

Video recorded accounting lectures are not new. For a decade, every Brigham Young University (BYU) business student has learned accounting via the video-recorded CD lectures of Professor Norm 
Nemrow (Volmar, 2009). Nemrow explains: "Most students love the CDs because they allow them to learn the material at their own convenience and pace. They can pause the presentation to take better notes and watch it as many times as they need to understand difficult concepts" (Winters, 2001).

What is new is the proliferation of accounting lectures that are easily accessible via the internet. There are educational video websites that host recorded videos created by professors and universities. For example, iTunesU is a dedicated University area in Apple's iTunes Store that provides lectures from more than 1000 universities. This university content has had over 600 Million downloads since the service's introduction in 2007. Apple has brought iTunes to 123 countries, and $60 \%$ of its users come from outside the US (Etherington, 2011). Examples of accounting-related videos on iTunes include presentations by Stephan Zeff, Sue Haka, and Steve Fortin.

An emerging educational video website that we favor is Udemy.com, as it goes one step further by offering similar video hosting as well as all the services needed to actually prepare a recorded online lesson. Udemy's tools include mashups (synchronization of video with PowerPoint), electronic whiteboards, and chat. Udemy provides all of its video hosting and online presentation tools at no cost. More than 2000 courses have been created with Udemy (Schomer, 2010). Courses by Susan Crosson are now hosted on Udemy in addition to YouTube.

\subsection{Pioneers in the creation of online asynchronous educational and accounting videos}

The most prolific creator of asynchronous educational videos is Salman Khan and his Khan Academy (www.khanacademy.org). Khan Academy hosts more than 2300 videos and has had more than 58 million viewers. Remarkably, all videos have been created by a single person, Salman Khan. Subjects include basic arithmetic to algebra, calculus, finance, history, and many current topics. The simple Khan online video format of explaining the concepts on a notepad has proven to be invaluable for delivering content to developing nations. Through a partnership with World Possible, a Californiabased nongovernmental organization (NGO), Khan is now supplying the educational content to classrooms in Sierra Leone, Ethiopia, and Ecuador (Massey, 2010). Bill Gates supports the Khan Academy and uses it to educate his children in math. Both the Gates Foundation and Google have awarded significant funding to help expand the academy and translate its lessons into additional languages.

Susan Crosson of Santa Fe College can be considered the "Khan Academy of Accounting Education." Crosson uses YouTube for sharing her accounting knowledge and has created more than 200 YouTube videos that can be used as a supplement to her own or other introductory accounting textbooks. Crosson has created two broad categories of her videos-Financial and Managerial-and has linked the groupings to the two textbooks that she uses for these courses. The classification of the videos can be viewed at her YouTube Channel (http://www.youtube.com/user/SusanCrosson). Crosson also provides a more detailed description, including the integration of the videos into her coursework, on her online course website (http://dept.sfcollege.edu/business/susan.crosson/Spring2011/S112021index.htm).

Marian Powers of Northwestern University has also created over 75 videos to complement the Needles-Powers accounting principles textbook. Unlike Crosson, Powers' videos are only available on the Cengage website. Powers has plans to create more videos in the future. Larry Walther, Director of the School of Accountancy at Utah State University and President of the Federation of Schools of Accountancy (FSA), has also created a YouTube channel that complements his free online Financial Accounting textbook and learning center (http://www.youtube.com/user/larrywalther), a project he began in 1998. Walther started making videos in 2010 and now has over 100 videos designed to complement his learning center and appeal to the more visual-learning student.

Peter (former AAA president) and Carolyn Wilson of Boston College, on their website www.navigatingaccounting.com, cite a 2007 FASB-AAA panel, in which several participants argued that "accounting education has not kept pace with the dramatic changes in business practices and financial reporting during the past twenty years" (Wilson \& Wilson, 2010). To fill in this "gap" and to simplify accounting concepts, Peter and Carolyn Wilson utilize video. Following a 2009 CTLA Master Class presentation in New York City, they were encouraged and inspired by more than 150 professors in attendance to make a series of Camtasia videos on accounting judgment. Thus, they created a 10-part series of online videos and exercises that are available to professors and students worldwide. Table 9 provides a selection of online lectures created by accounting professors. 
Table 9

Selected accounting professor online lectures.

\begin{tabular}{|c|c|}
\hline Accounting professors and description of their online lectures & Online lecture sources \\
\hline $\begin{array}{l}\text { Susan Crosson of Santa Fe College explains Accounting in over } 200 \\
\text { videos }\end{array}$ & www.youtube.com/user/SusanCrosson \\
\hline $\begin{array}{l}\text { Larry Walther of Utah State University explains Accounting in over } 100 \\
\text { videos }\end{array}$ & www.youtube.com/user/LarryWalther \\
\hline $\begin{array}{l}\text { Peter and Carolyn Wilson of Boston College, "Helping Students Make } \\
\text { Informed Judgments" }\end{array}$ & www.navigatingaccounting.com \\
\hline $\begin{array}{l}\text { Stephen Coetzee and Astrid Schmulian of the University of Pretoria, } \\
\text { "IFRS Rookies Channel" }\end{array}$ & www.youtube.com/user/IFRSrookies \\
\hline $\begin{array}{l}\text { Miklos Vasarhelyi, Rutgers University, "The Coming Age of Continuous } \\
\text { Auditing," } 71 \text { st CPA Australia's- University of Melbourne Annual } \\
\text { Research Lecture }\end{array}$ & www.youtube.com/watch?v=Fyhyddc6 $\mathrm{H} 3 \mathrm{c}$ \\
\hline $\begin{array}{l}\text { David Fordham, James Madison University, "Internal Control" (3-part } \\
\text { video series) }\end{array}$ & $\begin{array}{l}\text { http://jmutube.cit.jmu.edu/content/fordhadr/ } \\
\text { playlist/3792/play (also } 3793 \text { and 3813) }\end{array}$ \\
\hline $\begin{array}{l}\text { Rebecca Trax, Indiana University, "Accounting and the Business } \\
\text { Environment" }\end{array}$ & www.imds.iu.edu/imds/A186bb.shtml \\
\hline $\begin{array}{l}\text { Sue Haka, Michigan State University, "Accounting at a Tipping Point: } \\
\text { The Ascent of the Finance Industry" }\end{array}$ & www.apple.com/education/itunes-u \\
\hline $\begin{array}{l}\text { Stephan Zeff, Rice University, "The Primacy of 'Present Fairly' in the } \\
\text { Auditor's Report," a lecture hosted by CUNY-Baruch College }\end{array}$ & www.apple.com/education/itunes-u \\
\hline $\begin{array}{l}\text { Steve Fortin, McGill University, "Creative Accounting: Interpreting } \\
\text { Financial Statements in a Post-Enron World" }\end{array}$ & www.apple.com/education/itunes-u \\
\hline
\end{tabular}

In an effort to more closely integrate educational videos with text material, Professor Joe Hoyle of the University of Richmond, in his online Financial Accounting book, introduces and closes all seventeen book chapters with an online video (University of Richmond, 2009). In his opening video Hoyle points out that today's students are much more used to learning from videos. Hoyle states that students often struggle to read chapters and are often thrown into a chapter with very little preparation. According to Hoyle, students benefit from a video introduction before reading a chapter. Each video explains what is important in the chapter and why students should read and think about it. This provides motivation for the students and gives students the opportunity to understand the significance of each chapter before they study it. The Hoyle online book also closes each chapter with a video. The students are asked to list their opinion of the five most important topics in the chapter and then the closing video provides the perspective of the authors as to the most important issues to have been learned. The goal is to stimulate the students to reflect on what they have learned in the chapter.

In addition to the aforementioned video creation by individuals, various university business schools are embracing and promoting video creation and lecture capture. Table 10 shows examples of business schools that have uploaded many lectures into University Video Channels.

The future of asynchronous online education can be seen at the London School of Business \& Finance (LSBF), which in 2010 initiated the online LSBF Global MBA. LSBF provides hundreds of hours of freely accessible HD online video content. Students only pay tuition once they decide to go forward with formal accreditation (examinations). Online lectures are provided from faculty and panel discussion groups include partners from firms such as Accenture Management Consulting and from Deloitte. To

Table 10

Selected business school online video repositories.

\begin{tabular}{ll}
\hline Business school & Video source \\
\hline $\begin{array}{l}\text { Cornell Charles H. Dyson School of Applied Economics and } \\
\quad \text { Management }\end{array}$ & http://eclips.cornell.edu \\
MIT Sloan School of Management & http://ocw.mit.edu/courses/sloan-school-of- \\
& management \\
Wharton School of Business of the University of Pennsylvania & wwwarton.upenn.edu/videos \\
Stanford Graduate School of Business & www.youtube.com/user/stanfordbusiness \\
UC Berkeley Haas School of Business & www.youtube.com/user/UCBerkeleyHaas \\
\hline
\end{tabular}


incorporate the latest business events three state-of-the-art studios on LSBF's London campus continuously record and create updated study material (London School of Business, 2010). For the benefit of accounting students and practitioners worldwide, LSBF also offers video enhanced online courses leading to a variety of accounting and auditing certifications by the UK-based Association of Chartered Certified Accountants (ACCA) and the Institute of Chartered Accountants in England and Wales (ICAEW).

In addition to the educational video websites mentioned, many universities are establishing their own video lecture capture systems. Peter and Carolyn Wilson use lecture capture to record video and audio during classroom lectures and to make it available on Blackboard. Peter Wilson states: "Lecture capture specifically allows students to learn at their own speed, to stop the tape and go back when something gets more complex." Technology allows them to cover more content by exporting it from the classroom to the internet, while maintaining in-depth conversations in class. Peter Wilson states: "You might think with lectures posted online that students don't come to class, but we've found that just the opposite is true. Students come and they are more engaged" (McClary, 2011).

A University of Wisconsin Online Learning Study showed that the vast majority of students prefer lecture capture (Veeramani \& Bradley, 2008). A 2011 study of nearly 2000 students from 17 universities revealed that students selected lecture capture as the most important blended learning technology resource (Echo360, 2011). Purdue University has recently installed lecture capture systems in 280 classrooms. Edward Evans, interim executive director of teaching and learning technologies at Purdue University, states: "Increasingly, we find students expect constant access to learning resources regardless of the time and their location" (Echo360, 2007).

The authors of this article have received a Curriculum Development Grant from the Purdue University Center for International Business Education and Research (CIBER). The purpose of the grant is to create a series of video podcasts to educate students and professors about the issues surrounding the US adoption and/or convergence of IFRS. The project is entitled "The Creation of Educational Video Podcasts for International Financial Reporting Standards (IFRS) and a Video Channel Website." We look forward to creating these videos utilizing the asynchronous video technologies discussed herein.

\section{How to stay current with video technology}

Given the rapid pace of change, how can accounting faculty keep current with the trends and applications of video technology? A discussion of possible strategies is offered below.

\subsection{Conference on teaching and learning in accounting (CTLA)}

A great way to learn about using video is to attend the Conference on Teaching and Learning in Accounting (CTLA). Founded in 2008, the CTLA is a "conference within a conference," devoted solely to the advancement of the craft of teaching (Wygal, 2009). The CTLA is held during the two days preceding the AAA Annual Meeting.

Many CTLA sessions have explored the application of digital video technologies. Topics have included teaching with YouTube, Second Life, Skype, Wimba, Flip and Kodak camcorders, Camtasia, Smartpen pencasts, podcasts, video clips, and student video projects. The instructional format ranges from large-audience Master Classes to more intimate hands-on roundtables and workshops. The authors have been CTLA faculty and steering committee members for the past three years and have found attending the CTLA sessions to be a very rewarding experience.

\subsection{AAA Commons, discussion boards and technology websites}

The AAA Commons (http://commons.aaahq.org) is a collaborative social-networking platform designed to share ideas about teaching, research, and service. Among its many postings are presentations and discussions on teaching with video. Archived CTLA presentations from previous years, many that are video related, can be accessed on the AAA Commons. Rick Lillie of California State University San Bernardino contributes to the AAA Commons via his blog "Teaching with Technology," which also includes postings on using video. 
Table 11

Author recommendations for staying current with video technology.

\begin{tabular}{ll}
\hline Recommendations for Staying Current with Video Technology & Link \\
\hline 1. Conference on Teaching and Learning in Accounting (CTLA) & http://aaahq.org/AM2011/CTLAinfo.cfm \\
2. AAA Commons, Technology Discussion Boards \& Websites & http://commons.aaahq.org/pages/home \\
- AAA Commons (with archived CTLA presentations) & http://aecm.org \\
- Accounting Education Using Computers \& Multimedia (AECM) & http://trinity.edu/rjensen/ \\
- Bob Jensen's Videos and Other Helpful Tutorials & http://cs.trinity.edu/ rjensen/temp/ \\
- 2010 CTLA Master Class Handout (Holtzblatt \& Tschakert) & VideoExpaning_Your_Classroom_CTLA_2010.pdf \\
'Expanding your Classroom with Video Technology' & http://freetech4teachers.com/ \\
- 'Free Technology for Teachers' blog by Richard Byrnes & http://technologyintegrationineducation.com/ \\
- 'Technology Integration in the Classroom' online community & \\
- moderated by Greg Limperis & http://eschoolnews.com/ \\
- eSchool News-Technology News for Today's K-20 Educator & http://linkedin.com/ \\
3. Linkedin.com education and technology groups & http://google.com/alerts \\
4. Google news alerts for video technology and education & \\
\hline
\end{tabular}

Another online forum that frequently provides commentary on new technologies and links to accounting video clips is AECM - Accounting Education Using Computers and Multimedia (http://www. aecm.org), hosted on the AAA website. A prolific contributor to both the AAA Commons and AECM is Robert E. (Bob) Jensen, Accounting Professor (Emeritus) at Trinity University. Jensen has created numerous websites that offer vast information on technology, video and education (www.trinity.edu/rjensen). One of his websites, "Videos and Other Helpful Tutorials" links to our 6-page 2010 CTLA Master Class handout containing video resources (http://www.trinity.edu/rjensen/HelpersVideosSummary.htm).

We also gather many ideas from various technology websites such as a blog by Richard Byrnes, entitled "Free Technology for Teachers" (www.freetech4teachers.com), an online community moderated by Greg Limperis, "Technology Integration in the Classroom" (www.technologyintegrationineducation.com) and the electronic newsletter, "eSchool News - Technology News for Today's K-20 Educator" (www.eschoolnews.com).

\subsection{Linkedin.com education and technology groups}

Linkedin.com is an online community of more than 100 million professionals that exchange connections, ideas, and information. A free membership provides access to many special interest group discussions, including those pertaining to the use of technology in education. Three groups in this category are: Technology Integration in Education (TIE); Higher Education Teaching and Learning (HETL); and Technology-Using Professors.

\subsection{Google news alerts for video technology and education}

An effective way to stay apprised of video trends in near real-time is to create a Google Alert (www.google.com/alerts), which will deliver to your email account information from news reports, blogs, and discussion boards. For example, we have set up alerts that include the following phrases: (1) Video and Education; (2) Technology and Education; (3) Lecture Capture; (4) IFRS Video; (5) Forensic Video and (6) Sustainability Video. The alerts can be customized to your specific interests and can be delivered either once a week or once a day.

Our recommendations for staying current with video technology are summarized in Table 11.

\section{Areas for future research and a call to action for accounting educators}

\subsection{Areas of future research}

Within the accounting literature, there has been very little empirical research regarding the use of the video technologies described herein. Future studies may empirically examine the effects of using 
video technology to improve the teaching and learning process in accounting. Specifically, future research may examine how video technology improves knowledge acquisition and retention in accounting. Another interesting question relates to the factors that have driven faculty to explore the use of video technologies. If the incentives that stimulate certain professors to use these technologies are known, perhaps more accounting faculty could be motivated to experiment with and explore these tools.

\subsection{A call to action for accounting educators}

There are many exciting developments occurring with video technology in regards to network infrastructure, handheld devices, and website services. Looking at the rapid development in the past as well as industry presentations regarding future products, it is safe to predict that technology will continue to improve and become even more user friendly. These trends impact accounting education by providing many new opportunities for professors to re-think how they teach different accounting topics. These new resources can increase student motivation, increase the rigor and depth of learning, and more fully engage students in learning about accounting through the learned application of leading-edge 21st century communication tools. Whether exposing students to emerging topics and experts via the use of video clips, assigning student-created video projects, or globally distributing classroom activities (lectures and student presentations) via the internet, the possibilities are truly unlimited. Experimenting with Skype and online videos as a starting point is virtually risk-free and has the potential to greatly add to the classroom experience for both professors and their students. We encourage accounting professors to explore and become familiar with these developments and opportunities as the use of video technologies can provide stimulating complements to traditional accounting education.

\section{Acknowledgments}

The authors introduced the ideas contained herein during the 2010 CTLA Master Class. We received very positive feedback from the attendees and would like to thank in particular Robert E. (Bob) Jensen, Trinity University Accounting Professor (Emeritus), for his comments and inspiration. Professor Jensen wrote on the AAA Commons as well as on his own website (Jensen, 2010):

One of the most exciting things I took away from the 2010 AAA Annual Meeting in San Francisco is a hard copy handout entitled "Expanding Your Classroom with Video Technology and Social Media," by Mark Holtzblatt and Norbert Tschakert...This is an exciting listing to over 100 video clips and full-feature videos that might be excellent resources for your courses, for your research, and for your scholarship in general. Included are videos on resources and useful tips for video projects as well as free online communication tools. My thanks to Professors Holtzblatt and Tschakert for this tremendous body of work that they are now sharing with us.

\section{References}

American Accounting Association (AAA) (2010). Susan V. Crosson receives AAA outstanding service award. Accounting Education News, Fall 2010, 7.

American Institute of Certified Public Accountants (AICPA) (2010). AICPA launches college-level competition on accounting for sustainability. <http://www.aicpa.org/press/pressreleases/2010/pages/aicpalaunchessustainabilitycompetition.aspx> 15.09.10.

Apple Inc. (2010). Apple iPhone 4: In so many ways it's a first. http://www.apple.com/iphone/features 13.09.10.

Beatty, R. (2011). Global Collaboration, [PowerPoint Slides], Paper presented at a plenary panel session of the 2011. Canadian Academic Accounting Association (CAAA), Toronto, Canada.

Best, K. (2010). Telepresence keeps Darla Moore School of Business at the Top. <http://blog.tandberg.com/industry-applications/ education/telepresence-keeps-darla-moore-school-of-business-at-the-top> 22.12.10.

Burton, J. (2010). UC strategies experts discuss cisco announcements. <http://www.ucstrategies.com/UC-Experts-Discuss-CiscoAnnouncements.aspx>13.09.10.

Carver, S., Lehrer, R., Connell, T., \& Erickson, J. (1992). Learning by hypermedia design: Issues of assessment and implementation. Educational Psychology, 27 (3), 385-404.

Chen, B. (2009). How the iPhone could reboot education. <http://www.wired.com/gadgetlab/2009/12/iphone-universityabilene> 01.10.10. 
Churches, A. (2008). Bloom's taxonomy blooms digitally. <http://www.techlearning.com/article/blooms-taxonomy-bloomsdigitally/44988> 14.09.11.

Cisco Systems (2010a). Duke University MBA Students Use Cisco Quad Social Software to Collaborate Across Borders. Cisco Press Release on December 16, 2010. <http://www.marketwire.com/press-release/duke-university-global-mba-students-usecisco-quad-social-software-collaborate-across-nasdaq-csco-1370050.htm> 22.12.10.

Cisco Systems (2010b). Duke University Extends Global Learning with Cisco TelePresence Lecture Hall. Cisco Press Release on February 10, 2010. <http://newsroom.cisco.com/dlls/2010/prod_021010.html> 13.10.10.

Corporation for Public Broadcasting (2004). Television Goes to School: The impact of video on student learning in formal education. <http://www.dcmp.org/caai/nadh173.pdf> 20.08.11.

CPE Link (2010). CPE link and AccountingWEB Cooperate to Enrich University Accounting Curriculum. CPE Link Press Release on December 17, 2010. <http://www.prweb.com/releases/CPELink/12/prweb8027955.htm> 19.12.10.

David, J. S. (2011a). What's the value of video? AAA commons blog post of September 16, 2011. <http://commons.aaahq.org/ posts/3a325f862f> 17.09.11.

David, J. S. (2011b). A gem from CTLA at Midwest: YouTube videos for class. AAA Commons Blog post of October 17, 2011. $<$ http://commons.aaahq.org/posts/e712dae7dc> 17.10.11.

Echo360 (2007). Purdue Boilercasts selects Echo360 to power largest Lecture Capture Project in Higher Education. Echo360 Press Release on October 23, 2007. <http://echo360.com/news-events/press-releases/pr102307> 28.08.10.

Echo360 (2011). Students rank lecture capture 'Most Important' blended learning resource. Echo360 Press Release on June 7 , 2011. <http://echo360.com/news-events/press-releases/pr060711>09.06.11.

Ellis, R., \& Childs, M. (1999). The effectiveness of video as a learning tool in online multimedia modules. Journal of Educational Media, 24 (3), 217-223.

Erumi, T. R. (2010). Bridgeit: Empowering teachers with video via mobile phones. <http://edutechdebate.org/meducationinitiatives/bridgeit-empowering-teachers-with-video-via-mobile-phones> 22.12.10.

Etherington, D. (2011), iTunes U Doubles Downloads in Last Year Alone, the AppleBlog, September 8, 2011. <http://gigaom.com/ apple/itunes-u-doubles-downloads-in-last-year-alone> 23.09.11.

Fleming, N. D. (1995). I'm different, not dumb. Modes of presentation (VARK) in the tertiary classroom. In: Zelmer, A. (Ed.), Research and development in higher education, proceedings of the 1995 annual conference of the higher education and research development society of Australasia (HERDSA) (Vol. 18, pp. 308-313).

Gardner, H. (2006). Multiple intelligences. New Horizons. New York: Basic Books.

Garrett, J. (2010). Accounting, YouTube and the national stage. <http://news.sfcollege.edu/read.php/2010/08/12/professorsusan-crosson.html> 07.09.10.

Gillespie, D. (2007). On-demand video system enhances visual learning. District Administration, 43(9), 25-26.

Hedge, S., Useem, A., \& Martinez, S. (2011). Engaging with business learning: The source and medium do matter. Whitepaper prepared for Big Think, May 25, 2011. <http://assets.bigthink.com/WhitePaperv1.pdf> 25.05.11.

Holtzblatt, M., \& Tschakert, N. (2011). Experiential learning via an innovative Inter-University IFRS student video competition. Accounting Education: An International Journal, 20(4), 349-372.

Hood, T. (2010). CPA Island hosts conversation with MBAA, CPA Island Blog, March 26, 2010. <http://tomhoodcpa.typepad.com/ cpa_island/2010/03/index.html> 27.03.10.

Jensen, Robert E. (2010). Video and other helper tutorials - an absolute must read for educators. <http://www.trinity.edu/ rjensen/HelpersVideosSummary.htm> 20.10.10.

Jones, N. (2010). Nancy Jones on accounting 202, December 1, 2010. <http://www.youtube.com/watch?v=T-oaajXJKig> 18.07.11.

Jones-Kavalier, B.R., \& Flannigan, S.L. (2006). Connecting the digital dots: Literacy of the 21st Century, Educause Quarterly, 29. $<$ http://www.educause.edu/EDUCAUSE+Quarterly/EDUCAUSEQuarterlyMagazineVolum/ConnectingtheDigitalDotsLitera/ $157395>11.04 .11$.

Kaufmann, P. B., \& Mohan, J. (2009). Video use and higher education: Options for the future, copyright clearance center/ intelligent television/New York University 2009. <http://library.nyu.edu/about/Video_Use_in_Higher_Education.pdf> 10.08.10.

KPMG (2009). KPMG and NIIT imperia collaborate to launch advanced certificate program on IFRS - certificate programs will help companies and individuals to transition from Indian GAAP to IFRS, Press Release, November 4, 2009. <http:// www.kpmg.com/IN/en/Press\%20Release/NIIT-KPMG_release.pdf> 10.10.10.

Lavelle, L. (2010). Cisco technology helps duke MBA students 'Cross Continents'. <http://www.businessweek.com/bschools/ blogs/mba_admissions/archives/2010/12/cisco_technology_helps_duke_mba_program_cross_continents.html> 18.12.10.

London School of Business and Finance (2010). The London School of Business and Finance Offers Everybody Free MBA Classes Online - The revolutionary approach to education will change the way people teach, learn and gain MBAs forever - This is just the first step, Press Release, October 28, 2010. <http://www.lsbf.org.uk/globalmba/press-releases.html> 18.12.10.

Marshall, J. M. (2002). Learning with technology: Evidence that technology can, and does, support learning. White paper prepared for Cable in the Classroom by Dr. James M. Marshall, a member of the Department of Educational Technology at San Diego State University.

Massey, C. (2010). Virtual school helps students in US, South Asia, Worldwide. <http://www.america.gov/st/sca-english/2010/ October/20101027144111eirrac0.2723963.html> 23.11.10.

McClary, Christine (2011). Bringing new technology into 21st century classrooms. <http://www.bcheights.com/features/ bringing-new-technology-into-21st-century-classrooms-1.2007707?pagereq=2>16.06.11.

Moran, M., Seaman, J., \& Tinti-Kane, H. (2011). Teaching, learning, and sharing: How today's higher education faculty use social media, pearson learning solutions and babson survey research group. <http://www.pearsonlearningsolutions.com/ educators/pearson-social-media-survey-2011-bw.pdf> 20.09.11.

Saini, M. (2011). Davos: Explosion of video is next technological innovation. <http://blogs.forbes.com/miasaini/2011/01/26/ davos-explosion-of-video-is-next-technological-innovation> 15.06 .11

Schomer, S. (2010). Udemy: A free online university for all, December 2, 2010. <http://www.fastcompany.com/magazine/151/ fast-talk-gagan-biyani.html> 17.12.10. 
Schumacher-Rasmussen, E. (2011). Youtube for the enterprise finally a reality. <http://www.streamingmedia.com/Articles/ Editorial/Featured-Articles/YouTube-for-the-Enterprise-Finally-a-Reality-75952.aspx> 09.06.11.

Smith, L. M. (2011). International accounting syllabus - spring 2011. <http://acct.tamu.edu/smith/acct445.htm>03.01.11.

University of Richmond (2009). Joe Ben Hoyle: Award-winning accounting professor keeps teaching fresh after 30 years, Press Release, December 15, 2009. <http://news.richmond.edu/features/article/business/690/award-winning-accountingprofessor-keeps-teaching-fresh-after-30-years.html> 23.09.10.

University of Southern California (USC) (2010). USC Leventhal students skype their way to solving global business problems, Press Release, May 8, 2010. <http://www.marshall.usc.edu/news/all-articles/usc-leventhal-students.htm> 22.12.10.

Veeramani, R., \& Bradley, S. (2008). University of Wisconsin online-learning study: Insights regarding undergraduate preference for lecture capture. <http://www.uwebi.org/news/uw-online-learning.pdf> 29.08.10.

Volmar, P. (2009). Nemrow hopes influence will reach students. Universe (BYU). <http://universe.byu.edu/node/659>30.12.10.

Webb, L., De Lange, P., \& O'Connell, B. (2009). A programme to expose students to senior executives in the world of accounting: An innovative learning method. Accounting Education: An International Journal, 18(2), 183-205.

Wilson, P., \& Wilson, C. (2010). About navigating accounting. <http://www.navigatingaccounting.com> 03.01.11.

Winters, C. (2001). Teaching accounting for love, BYU Magazine, Spring, 2001. <http://magazine.byu.edu/?act=view\&a=62> 30.12.10.

Wygal, D. E. (2009). Building community: The conference on teaching and learning in accounting. Accounting Education: An International Journal, 18(1), 99-101.

Young, J. R. (2011). Across more classes, videos make the grade. The Chronicle of Higher Education. <http://chronicle.com/ article/Across-More-Classes-Videos/127422> 19.09.11. 